\title{
The role of primary care physicians in enabling validation of a patient's ability to make legal statements and express
} a last will

JAKUB TRNKA ${ }^{1, A, B, D}$, JAROSŁAW DROBNIK², A, D, ROBERT SUSŁO 2, A, D-F

${ }^{1}$ Department of Forensic Medicine, Faculty of Medicine, Wroclaw Medical University, Poland

${ }^{2}$ Department of Gerontology, Department of Public Health, Faculty of Health Sciences, Wroclaw Medical University, Poland

A - Study Design, B - Data Collection, C - Statistical Analysis, D - Data Interpretation, E - Manuscript Preparation, F - Literature Search, G - Funds Collection

Summary The expression of a last will is legally invalid when the will-maker was in a state preventing him or her from making a decision, or expressing will, in a conscious or independent way; this could occur due to psychiatric disorders, mental retardation, or any other mental activity disturbance, even temporary. There are many problems with medical opinions concerning the validity of last wills. Medical staff play an important and law-rooted role in providing valuable evidence in such cases. The forensic medical literature was searched for topics related to evaluations of last will and testament. Forensic opinions issued by the Forensic Medicine Department, Wrocław Medical University, Poland, in years 2006-2016 were also examined for cases illustrating the role of physicians and medical files in the legal evaluation of contested wills. This allowed us to conclude that mental status alterations that prevent patients from making last wills in a legally valid way can result from psychiatric or somatic disorders that negatively influencing the level of consciousness. Medical files are a highly valuable and trustworthy source of evidence - especially in the parts authored by medical staff in frequent contact with patients, which includes primary and palliative care physicians or nurses. It is necessary that these files contain remarks on the patient's behavior and ability to function in a home environment, as well as information shared by the patient's relatives. It is crucial that any drugs prescribed and their doses are recorded, and that the actual drugs administered to the patient are also noted.

Key words: forensic psychiatry, forensic medicine, medical records, family medicine, last will.

Trnka J, Drobnik J, Susło R. The role of primary care physicians in enabling validation of a patient's ability to make legal statements and express a last will. Fam Med Prim Care Rev 2017; 19(3): 319-322, doi: https://doi.org/10.5114/fmpcr.2017.69298.

\section{The legal foundations of effectively drawing up a last will and testament}

A will or testament can be described as a solemn and authentic instrument in writing by which a person expresses his or her will to dispose of belongings in a defined way. Wills have significant legal, formal, and ethical importance to both the will-maker (testator) and society [1]. Although in the United States, only $46 \%$ of population older than 25 years has a will [2], drawing up wills is a common everyday activity in many legal offices. Legal proceedings in courts aimed at questioning the validity of wills are comparably rare, but the medical legal opinions issued in such cases are both difficult and important in practice. Every person capable of possessing goods is typically able also to dispose of them freely, and drawing up a will is one way in which this can be done; the details of the process typically depend on the circumstances, health status, and the time available. Article 926 of the Polish Civil Code [3] states that inheritance from a deceased person can be indicated in law or by a valid last will. Where a valid last will exists, its instructions override the standard pattern of inheritance outlined in law. However, where there is no valid last will, or where a person it indicates as inheriting does not desire to inherit or is incapable of inheriting, standard inheritance law applies. Articles 951-958 of the Code outline several types of wills, each being associated with formal conditions that must be fulfilled for the will to be valid. In particular, wills may be either regular or special. A regular will can be holographic, allographic, or notary. A holographic will is one that was made in person, written and signed wholly in ink on paper. Allographic wills are those that were delivered orally in the presence of an official of the appropriate type and two witnesses, written down by them and signed by the testator, the official, and both witnesses. A notary will is one that is drawn up in the presence of a notary, and is thus considered the safest of the forms. It is most often made in the notary's office, but it can in fact be made practically anywhere, such as at a hospital or at the testator's home. The special wills include oral, military, and on-board will. Oral wills can be used in case of imminent death, or when the regular forms of will-making are unavailable for any reason. Military wills apply only to soldiers and can only be drawn up during a war, during a military mobilization, or in prisoner of war camps. An on-board will is one made on board a Polish ship or aircraft and must be expressed in front of the commanding officer and two other witnesses. Under normal circumstances, the notary will is the most common form; however, oral last wills are not exceptional in cases of medical emergencies [4].

\section{The medical legal approach to evaluating last wills}

In order to find appropriate examples of the problems that can accompany forensic medicine opinions on the validity of last wills, and the legally rooted role of medical staff in providing evidence in such cases, we searched the current forensic medicine literature for topics related to the evaluation of last wills and testaments. It is not uncommon in case of large-value inheri- 
tances that family members disagree with a last will. Those who were unexpectedly omitted from the last will are likely to try to undermine its validity. Such attempts can involve attempting to show that the required legal conditions were not fulfilled or to provide proof that the testator was not of testamentary capacity - typically because he or she was not of sound mind. Conversely, it also happens that the will was written by a person suspected of suffering from dementia, with its benefactors claiming that the document was nonetheless the product of a "lucid moment" [5]; such cases are often critically cited as examples of antiquated medical, or even nonscientific, terminology being abused by the legal profession [6]. It is also worth remarking that such legal claims occur with exhausting regularity, despite the fact that - especially in patients with dementia - such "lucid moments" are typically not very intense in effect and very short duration; they tend also to affect attention and alertness, rather than the functions crucial for testamentary capacity, such as memory and executive functions [7]. Among the wills most commonly questioned are those where a radical change from a previous will was observed; where undue influence is alleged; where the testator had no biological offspring; where the testament was made less than one year before the testator's death; and where the testator suffered from dementia or other psychiatric or neurological illness, or was alcohol dependent [8]. Other commonly identified factors that strongly suggesting an undue influence on older testators include social or environmental factors, such as dependency, isolation, family conflict, and recent bereavement; psychological and physical factors like physical disability, deathbed wills, sexual bargaining, personality disorders, substance abuse, and mental disorders; and legal factors including provisions in the will that are unnatural or inconsistent with previously expressed wishes, and initiatives that lead to the will being made out strongly in favor of a particular beneficiary [9]. In such dubious situations, courts routinely request expert opinions; these are typically provided by teams of forensic medicine and specialists of other medical branches - in particular psychiatry [10]. The types of last will most commonly evaluated by forensic medicine experts are the holographic, oral, and notary forms. According to Article 82 of the Polish Civil Code [3], a will is invalid if testator was, for any reason, in a state that prevented him or her making the decision, or expressing the will, in conscious or independent way; psychiatric disorders, mental retardation, and other disturbances in mental activity (even if temporary) are specifically mentioned. In such cases, the testator either lacked testamentary capacity or expressing the will under external influence [10]; these situations are often referred to insane delusion and undue influence, respectively [11]. A Polish article on will contests shows that a lack of testamentary capacity was observed in $46 \%$ of cases and that undue influence was proven in $40 \%$ of cases [12]. In every will contest, it must be determined whether the testator was able to create a coherent, rational testamentary structure that sufficiently connects beliefs, values, and relationships with the disposition of assets described in the will [13]. Forensic experts, optimally working in teams with specialists in forensic medicine, forensic psychiatry, and forensic psychology [14], primarily evaluate the quality of the will document itself, using handwriting analysis [15]; this allows the psychological state and personality to be assessed [16] and may demonstrate, among other things, severe cognitive impairment on the part of the testator [17]. Other information that can result from such an investigation includes data on the circumstances of the preparation of the will; statements from interviews with witnesses, including observations of everyday activities; and medical documents, including various pieces of internal and external medical documentation [18]. Medical documents that are collected and examined several years after the expression of the last will, as sometimes happens, tend to be incomplete or provide inadequate information on the person's mental state and ability to freely express their will. Those intending to prepare a will are therefore often advised to undergo an assessment by a physician, optimally by a psychiatrist [12]. Answering to the need for such evaluations, the Testament Definition Scale (TDS) was designed in attempt to measure the person's capacity to define a last will [19]. It must be stressed that those diagnosed with a mental disorder are not automatically considered unable to make a testament effectively: individual evaluation of each case is needed and the standard criteria include the understanding of the nature of a testament and codicil; the awareness of assets possessed and of the effect of their distribution; and the absence of any delusion that affects these, especially those resulting from dementia, mood disorder, schizophrenia, alcohol, drugs, and undue influence [20]. Both testaments written prior to suicide [21] and deathbed last wills are susceptible to challenge, as dying testators are often influenced by both strong emotions and many severe physical and psychological comorbidities, often coexisting; delirium in particular is highly prevalent among terminal patients and it makes it difficult for testators to avoid abuse and exploitation. On the other hand, a properly expressed last will is easily questioned on the same basis [22]. However, in an aging society, delirium episodes are observed with increasingly frequency, even among people who are far from terminal state [23].

\section{Contested testaments: the hands-on \\ experience}

Our literature review did not provide any well-documented and striking examples of the medical evaluation of last wills that fully demonstrated expert approaches and methodology. A review of the archive of forensic opinions of the Forensic Medicine Department, Wrocław Medical University, Poland, in the years 2002-2016 was therefore carried out. We found several cases that illustrated well the role of both physicians and medical files in the legal evaluation of the validity of a contested last will, and how such a will should be examined in line with the regulations of Polish civil law. One good example of a situation in which a testament was contested (Forensic Medicine Department, Wrocław Medical University, archive code OpAkt 40/2016) involved a woman, 58 years old, who expressed her last will orally on 11 February 2008; the will was subsequently converted to written form on 21 February 2008. She was ill with cancer of the tongue and throat received treatment on 29 November 2007 in an oncology teleradiotherapy facility. At that time she provided a medical history and was physically examined. She complained of pain in the right ear but her general health status was good, especially there was no mention of alterations in consciousness and no need of rehabilitative or psychological support. She was medically supervised by an ambulatory consultative oncology facility whose medical record lack any remarks regarding any alterations in consciousness. In the medical records dated 29 January 2007, there was a note that the patient complained that, having stood up and taken several steps, she "fainted" and collapsed; the incident was followed by a brief loss of consciousness. She reported that similar incidents had also occurred in the past, and she was therefore treated by a specialist neurologist who diagnosed her with cerebral blood flow insufficiency. Those incidents were rare, brief, and obvious to people in her vicinity; they followed rapidly standing up from the sitting position and were consistent with orthostatic low blood pressure, which is not a psychiatric condition. There were no mentions of fainting incidents in any other medical files or witness reports. At the same time, the patient was being treated at otolaryngology outpatient clinics: the medical files indicate that she had local lesions in the throat region, but did not mention any problems with disturbances in lucidity or consciousness. Hospitalization in a hospital radiotherapy and oncology ward, from 10 December 2007 to 6 February 2008, involving radiotherapy and chemotherapy, brought significant improvement to the patient's general health and mental status; 
the only abnormality documented was an acute post radiation reaction. On leaving the hospital, the patient received prescriptions for morphine, of which she made no use, as she was subjected to alternative palliative treatment at home. On 12 February 2008, the day after the oral last will was expressed, the physician treating the patient confirmed her grave somatic health status associated with the advancing cancer; the patient was, however, conscious and responsive; although she was in possession of morphine, she did not use it, as there still was no need for it. On that day she was instructed to take several medical drugs, including low doses of the strong neuroleptic haloperidol as an antiemetic. She vomited that day, but showed no signs of mental disturbance. Between the $12^{\text {th }}$ and $14^{\text {th }}$ of February, the nurses noticed not mental alterations and reported only somatic complaints. Also, the palliative care medical files from that time mention on deteriorating somatic health status, including symptoms of multiorgan failure, but still without any mental disturbances.

\section{Practical medical legal evaluation of contested wills}

The negative effect of various factors on a person's consciousness is not an uncommon problem in forensic medicine. In Poland, mental status alteration quite often results from acute or chronic ethanol abuse [24], acute drug abuse [25], and drug dependency [26]. On the other hand, paradoxically, physicians whose patients suffer from chronic pain need to be encouraged to introduce opioids into the treatment schemes, as they are often are overcautious or fear narcotic dependency or respiratory insufficiency [27]. Hypoxia is a well-known factor that severely alters mental status, causing deep confusion and hallucinations [28], which are now often seen as iatrogenic in origin [29] - the cause being accidental overdose or a failure in doctor-patient communication [30]. Consequently, proper documentation of medical history, of physical examination findings, and of treatments prescribed by physicians is of the greatest importance, not only for the continuous maintenance and improvement of quality of medical services and health related quality of life [31], but also for the legal safety of both patients and medical staff: using fragmented or inaccurate data may lead, among other undesirable outcomes, to incorrect forensic medical opinions in the case of suspected medical errors and contested wills [32]. Primary health physicians' activities are of the greatest importance, as they are the medical professionals with whom patients most often come into contact with (there being almost 160 million appointments for medical care annually in Poland) [33]. Polish law requires medical experts to determine a person's state of consciousness at the moment when the last will was expressed, based on the available evidence. The most common psychiatric disorders that are likely to alter consciousness are senile dementia, psychoorganic syndrome with dementia, depressive syndrome, paranoid syndrome, and schizophrenia.
There are also somatic disorders that are likely to affect mental activity, such as metastatic lung cancer, gastric cancer, ischemic heart attack, advanced cerebral atherosclerosis, chronic heart insufficiency, brain insult with hemiparesis and aphasia, and liver cirrhosis. In some cases, the inability to express a last will is only temporary and results from dynamic changes in the level of consciousness. It must be stressed that very advanced age by itself does not limit a person's ability to effectively express a last will [34]. In the case of the woman discussed earlier, a team of medical experts, in line with the law, examined the woman's medical record, finding no entries suggesting significant deterioration of cognitive functions, including memory, orientation, or consciousness; psychotic disorders were also ruled out. The medical staff who had dealt with the patient in February 2008 , including the ambulatory clinic physician who served as a witness to the patient's expression of her last will, did not observe any signs or symptoms that could be interpreted as resulting from significant mental disturbance. There was certainly significant deterioration in the somatic health status of the patient, but this did not interfere with her ability to make decisions and to express her will in a conscious and independent way. The patient was taking several drugs at the time, and had access to narcotic drugs, but none of the medicines which were actually taken caused any significant depression of mental function. All the evidence allowed the team of medical expert to issue an opinion stating that there were no medical factors making the patient unable to express a valid last will at that time.

\section{Guidelines for primary care physicians}

Fulfillment of the merely formal and legal requirements is not always sufficient to make (and keep) a will valid. In case of doubt, it is also necessary to evaluate the consciousness of the person at the moment of expressing the last will. Mental status alterations that prevent a patient from making a last will with legal validity can result from psychiatric and somatic disorders that negatively affect the level of consciousness. Medical files are a highly valuable and trustworthy source of evidence, especially in those parts authored by medical staff in frequent contact with patients, including primary and palliative care physicians and nurses. For the purposes of evaluating a contested last will, it is important that these files contain information on the patient's behavior and ability to function in the home environment, as well as information shared by the patient's relatives. If the medical files are to allow not only evaluation of the patient's mental status at the moment of expressing the will, but also tracing of the dynamics of the patient's consciousness over longer periods, it is crucial that all pharmacotherapy be properly documented. The medical file should contain clear remarks on drugs prescribed and their doses, as well as notes on the scheme actually followed by the patient - only such an approach can make it possible to trace the drugs' probable influence on the patient's level of consciousness.

Source of funding: This work was funded by the authors' resources. Conflict of interest: The authors declare no conflict of interests.

\section{References}

1. Novaković M. Testament's ability in Balkan endemic nephropathy. Med Preg/ 2009; 62(5-6): 268-272 (Abstract).

2. Greenberg M, Weiner M, Greenberg G. Risk-reducing legal documents: controlling personal health and financial resources. Risk Anal 2009; 29(11): 1578-1587.

3. Ustawa z dnia 23 kwietnia 1964 r. Kodeks cywilny (Dz.U. $1964 \mathrm{nr}$ 16, poz. 93, with subsequent amendments) [cited 27.06.2017]. Available from URL: http://isap.sejm.gov.pl/Download?id=WDU19640160093\&type=3 (in Polish).

4. Cloutier F, Moreau D, Tremblay N, et al. Means of communicating one's last will and testament. Infirm Que 1999; 7(1): 18-22.

5. Merikangas J. Commentary: contested wills and will contests. J Am Acad Psychiatry Law 2015; 43(3): 293-297.

6. Rodgers C, Baird J. The lucid interval-coping with unscientific terminology. J Am Acad Psychiatry Law 2015; 43(3): 298-299. 
7. Shulman K, Hull I, DeKoven S, et al. Cognitive fluctuations and the lucid interval in dementia: implications for testamentary capacity. J Am Acad Psychiatry Law 2015; 43(3): 287-292.

8. Shulman K, Cohen C, Hull I. Psychiatric issues in retrospective challenges of testamentary capacity. Int J Geriatr Psychiatry 2005; 20(1): 63-69.

9. Peisah C, Finkel S, Shulman K, et al. The wills of older people: risk factors for undue influence. Int Psychogeriatr 2009; 21(1): 7-15.

10. Feuerstein S, Coric V, Morgan CA, et al. The last will and testament and the psychiatrist. Psychiatry (Edgmont) 2006; 3(5): 18-29.

11. Roof J. Testamentary capacity and guardianship assessments. Psychiatr Clin North Am 2012; 35(4): 915-927.

12. Marcinkowski J, Klimberg A. Opiniowanie sądowo-lekarskie w sprawach o unieważnienie testamentu. Cz. II. Wnioski końcowe opinii. Jakość dokumentacji lekarskiej. Ocena zeznań świadków. Arch Med Sad Kryminol 2007; 57(1): 42-48 (in Polish).

13. Shulman K, Peisah C, Jacoby R, et al. Contemporaneous assessment of testamentary capacity. Int Psychogeriatr 2009; 21(3): 433-439.

14. Skupień E, Kowanetz M. Psychiatryczno-psychologiczne opiniowanie w sprawach o unieważnienie oświadczenia woli ze szczególnym uwzględnieniem oceny swobody. Arch Med Sad Kryminol 2008; 58(1): 37-42 (in Polish).

15. Fontana P, Dagnino F, Cocito L, et al. Handwriting as a gauge of cognitive status: a novel forensic tool for posthumous evaluation of testamentary capacity. Neurol Sci 2008; 29(4): 257-261.

16. Schiegg M, Thorpe D. Historical analyses of disordered handwriting: perspectives on early 20th-century material from a German psychiatric hospital. Writ Commun 2017; 34(1): 30-53.

17. Balestrino $\mathrm{M}$, Fontana $\mathrm{P}$, Terzuoli $\mathrm{S}$, et al. Altered handwriting suggests cognitive impairment and may be relevant to posthumous evaluation. J Forensic Sci 2012; 57(5): 1252-1258.

18. Marcinkowski J, Klimberg A. Opiniowanie sądowo-lekarskie w sprawach o unieważnienie testamentu. Cz. I. Charakterystyka materiału badawczego. Charakterystyka testatorów. Arch Med Sad Kryminol 2007; 57(1): 34-41 (in Polish).

19. Heinik J, Werner P, Lin R, How do cognitively impaired elderly patients define „testament”: reliability and validity of the testament definition scale. Isr J Psychiatry Relat Sci 1999; 36(1): 23-28.

20. Pang $Y$, Cai W, Zhang Q, et al. Advanced investigation of testamentary capacity of the mentally disordered. Fa Yi Xue Za Zhi 2009; 25(3): 208-211 (Abstract).

21. Shulman K, Hull I, Cohen C. Testamentary capacity and suicide: an overview of legal and psychiatric issues. Int J Law Psychiatry 2003; 26(4): 403-415.

22. Peisah C, Luxenberg J, Liptzin B, et al. Deathbed wills: assessing testamentary capacity in the dying patient. Int Psychogeriatr 2014; 26(2): 209-216.

23. Liptzin B, Peisah C, Shulman K, et al. Testamentary capacity and delirium. Int Psychogeriatr 2010; 22(6): 950-956.

24. Trnka J, Susło R, Drobnik J. Lekarz rodzinny wobec zjawiska nadużywania alkoholu przez pacjentów. Przew Lek 2010; 2: 184-187 (in Polish).

25. Drobnik J, Susło R, Trnka J. Ostre zatrucia substancjami psychoaktywnymi jako praktyczny problem lekarza rodzinnego. Przew Lek 2010; 2: 131-134 (in Polish).

26. Susło R, Drobnik J, Trnka J. Rozpoznawanie i dokumentowanie przypadków przewlekłej intoksykacji wśród pacjentów podstawowej opieki zdrowotnej. Przew Lek 2010; 2: 180-183 (in Polish).

27. Dobrogowski J, Wordliczek J, Szczudlik A, et al. Zasady stosowania silnie działających opioidów u pacjentów z bólem przewlekłym pochodzenia nienowotworowego - przegląd piśmiennictwa i zalecenia Polskiego Towarzystwa Badania Bólu, Polskiego Towarzystwa Neurologicznego i Polskiego Towarzystwa Medycyny Rodzinnej. Ból 2015; 16(3): 9-30 (in Polish).

28. Susło R, Trnka J, Siewiera J, et al. Hypoxia-related brain dysfunction in forensic medicine. In: Advances in Experimental Medicine and Biology. Vol 837. Pokorski M, ed. Neurotransmitter Interactions and Cognitive Function. Cham: Springer; 2014: 49-56.

29. Susło R, Trnka J, Siewiera J, et al. Ondine's curse - genetic and iatrogenic central hypoventilation as diagnostic options in forensic medicine. In: Advances in Experimental Medicine and Biology. Vol 861. Pokorski M, ed. Respiratory Health. Cham: Springer; 2015; 861: 65-73.

30. Drobnik J, Susło R, Trnka J, et al. Znaczenie prawidłowego udzielania pacjentom informacji o lekach w kontekście zagrożeń w ruchu drogowym i miejscu pracy. Fam Med Prim Care Rev 2011; 13(2): 302-304 (in Polish).

31. Kanecki K, Nitsch-Osuch A, Tyszko P. Health-Related Quality of Life or Quality of Medical Service? Current challenges for family doctors. Fam Med Prim Care Rev 2016; 18(3): 382-386.

32. Susło R, Trnka J, Drobnik J, et al. Sposób sporządzania dokumentów medycznych jako przyczyna błędu opiniodawczego. Fam Med Prim Care Rev 2009; 11(3): 506-508 (in Polish).

33. Tyszko Z, Nitsch-Osuch A, Mińko M, et al. Primary health care tasks in implementing the main operations of public health. Fam Med Prim Care Rev 2016; 18(3): 394-397.

34. Trnka J, Brużewicz S, Świątoniowski G, et al. Czy osoby w podeszłym wieku mogq świadomie sporzqdzić testament? In: Kowaleski J, Szukalski P, eds. Starość $i$ starzenie się jako doświadczenie jednostek i zbiorowości ludzkich. Łódź: Zakład Demografii Uniwersytetu Łódzkiego; 2006: 262-264 (in Polish).

Tables: 0

Figures: 0

References: 34

Received: 30.06 .2017

Revised: 04.07.2017

Accepted: 11.08.2017

Address for correspondence:

Jakub Trnka, MD, PhD

Zakład Medycyny Sądowej UM

ul. Mikulicza-Radeckiego 4

50-345 Wrocław

Polska

Tel.: +48 71 784-14-72

E-mail: jakub.trnka@umed.wroc.pl 